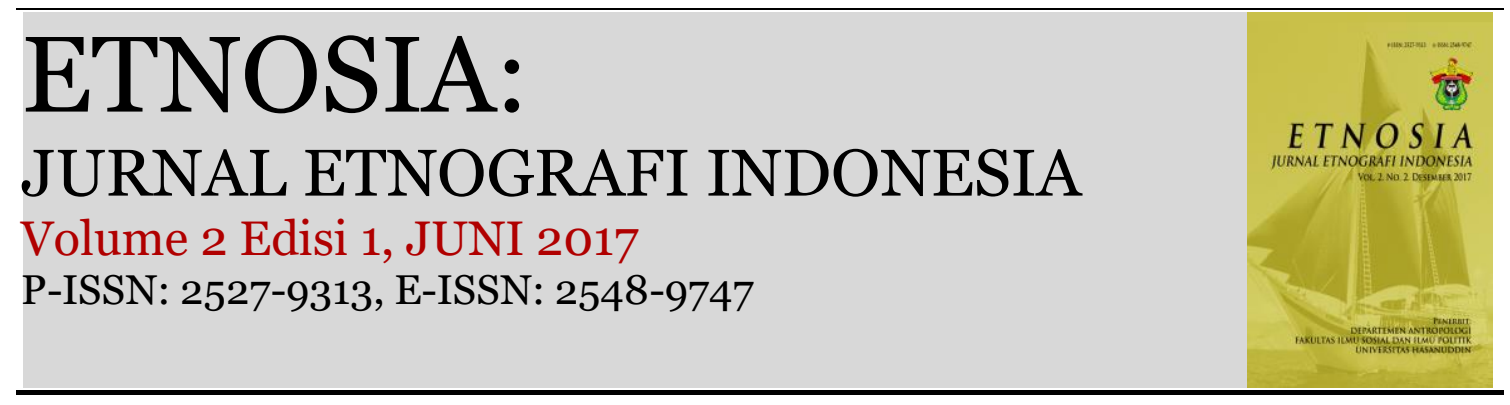

\title{
Memenangkan Pasar Pembiayaan: Studi Kasus Strategi Bisnis PT. Armada Finance di Makassar
}

\section{Safriadi}

Departemen Antropologi, FISIP Universitas Hasanuddin. E-mail: safriadi65@yahoo.co.id

\begin{tabular}{|c|c|}
\hline ARTICLE INFO & ABSTRACT \\
\hline $\begin{array}{l}\text { How to cite: } \\
\text { Safriadi. (2017). } \\
\text { Memenangkan Pasar } \\
\text { Pembiayaan: Studi Kasus } \\
\text { Strategi Bisnis PT. } \\
\text { Armada Finance di } \\
\text { Makassar. Etnosia: Jurnal } \\
\text { Etnografi Indonesia. } \\
\text { 2(1):55-73. }\end{array}$ & $\begin{array}{l}\text { With the proliferation of finance companies, companies are always } \\
\text { trying to be existed in the middle of business competition through } \\
\text { various strategies to win the market without violating the relevant } \\
\text { government regulation. This article aims to explore how to deal with } \\
\text { financing breach agreement, the existing strategies applied by the } \\
\text { company, and how these are related to the regulation of Bank } \\
\text { Indonesia. The research findings indicate that as a profit } \\
\text { organisation, PT. Armada Finance, apllies syariah principle on the } \\
\text { basis of murabahah without violating the regulation of Bank } \\
\text { Indonesia. Despite the fact that the transaction between the company } \\
\text { and the customers is always pursued in accordance with the rules, in } \\
\text { case of breach agreement which includes default, transfer of } \\
\text { warranty, emblezzment of collateral, the completion is adjusted with } \\
\text { the type of deviation and the risk resulted toward the company, } \\
\text { without neglecting Islamic business ethics, as one of the uniqueness } \\
\text { of this finance company. Various strategies have been applied by the } \\
\text { company, not only those established institutionally, but also on the } \\
\text { basis of individual creativity, and they are complementary in } \\
\text { practice. As finance company is mushrooming and becomes more } \\
\text { competitive, breakthrough related to strategies should always be } \\
\text { improved and are in accordance with marke needs. }\end{array}$ \\
\hline
\end{tabular}

Copyright (C) 2017 ETNOSIA. All rights reserved.

\section{Pendahuluan}

Salah satu faktor yang memengaruhi kinerja dari sebuah organisasi adalah budaya kerja dalam organisasi tersebut. Budaya kerja menjadi elemen kunci dari perubahan yang memberi pengaruh kuat bagi sistem kerja organisasi, dan menjadi pedoman berperilaku dalam lingkup organisasi (Sutrisno 2011:23-27). Schein (1992:1-3) dalam bukunya Organizational Culture and Leadership menyatakan bahwa budaya organisasi dikembangkan dari waktu ke waktu 
sebagaimana orang dalam organisasi belajar menuju kesuksesan dengan cara mengatasi masalah melalui adaptasi eksternal dan integrasi internal.

Budaya organisasi pada konteks perusahaan disebut juga budaya koorporasi atau budaya perusahaan. Hal ini dapat berupa aktivitas sehari-hari di perusahaan pada level manajemen maupun karyawan yang berhubungan dengan praktik bisnis perusahaan. Begitu besarnya pengaruh budaya korporasi, sehingga berdampak besar pada prestasi kerja organisasi, dengan melihat sisi ekonomi perusahaan dalam jangka waktu panjang, kesuksesan atau kegagalan perusahaan dalam dekade mendatang, kekokohan posisi keuangan dalam jangka panjang, dan kinerja karyawan (Kottler dan Heskett 1992:37). Dalam konteks serupa, Baba (2006:83) menggunakan konsep budaya bisnis untuk menjelaskan strategi pemasaran dalam membangun bisnis pada sebuah perusahaan atau korporasi. Salah satu unsur dari budaya bisnis adalah strategi berbisnis yang merupakan strategi yang berkaitan dengan pelaksanaan gagasan, perencanaan, dan eksekusi sebagai sebuah aktivitas dalam kurun waktu tertentu. Strategi sangat penting dalam persaingan bisnis yang semakin ketat dewasa ini dan menuntut pihak manajemen suatu perusahaan untuk menggunakan strategi pemasaran yang tepat bagi produk atau jasa layanan produk yang dijual.

Strategi dalam bisnis adalah model praktik-praktik berbisnis oleh perusahaan sebagai tindakan kolektif maupun kreativitas dalam rangka melanjutkan daur hidup perusahaan agar senantiasa eksis dalam bisnis yang dijalankan. Keberhasilan atau kegagalan suatu perusahaan umumnya terkait dengan strategi pemasaran, sehingga perusahaan harus meninjau dan mengembangkannya sesuai dengan perkembangan pasar (Prawia 2015; Gunawan 2013; Lubis 2004).

Meskipun strategi pemasaran bersifat universal, namun setiap perusahaan memiliki keunikannya masing-masing dalam menentukan berbagai strategi yang akan digunakan. Menurut Kottler dan Heskett (1992) strategi adalah proses manajerial untuk mengembangkan dan menjaga keserasian antara tujuan perusahaan, sumber daya perusahaan, dan peluang pasar yang terus berubah dengan tujuan untuk membentuk dan menyesuaikan usaha perusahaan dan produk yang dihasilkan sehingga bisa mencapai keuntungan dan tingkat pertumbuhan yang menguntungkan. Strategi, menurut Tjiptono (2002:6), menggambarkan arah bisnis yang mengikuti lingkungan yang dipilih dan merupakan pedoman untuk mengalokasikan sumber daya dan usaha suatu organisasi. Menyusun strategi berarti mencari jalan bagaimana mencapai hasil 
yang ditargetkan sesuai dengan visi dan misi di dalam situasi organisasi dan prospek yang dihadapi.

Artikel ini berfokus pada strategi-strategi yang digunakan oleh PT. Armada Finance dalam memenangkan pasar sebagai bentuk adaptasi terhadap faktor ekstenal perusahaan untuk dapat bersaing dalam dunia bisnis pembiayaan dengan mengedepankan segala keunggulannya sebagai perusahaan berbisnis dengan model syariah, salah satu ciri khasnya adalah bebas dari riba dan akad bisnisnya berupa kesepakan bersama sesuai dengan ajaran Islam.

\section{Metode Penelitian}

Penelitian ini dilakukan di PT. Armada Finance di Makassar sebagai sebuah perusahaan pembiayaan yang 'hidup' di Makassar. Perusahaan ini dipilih berdasarkan pertimbangan bahwa perusahaan ini merupakan pemegang beberapa penghargaan yang terkait dengan bisnis yang dijalankan. Penghargaan tersebut diperoleh dari Asosiasi Perusahaan Pembiayaan Indonesia (APPI) karena termasuk 10 perusahaan pembiayaan terbaik dengan asset diatas 500 milyar pada awal tahun 2014; Islamic Finance Award \& Cup (IFAC) selama tiga tahun berturut-turut (2011, 2012, 2013) karena menjadi peringkat pertama pembiayaan Islam terbaik yang dinilai berdasarkan jumlah besaran pembiayaan yang digunakan.

Dalam penelitian ini ada 10 orang informan yang dipilih secara purposive dari pemegang saham, direktur operasional, manajer, dewan syariah, supervisi, dan staf yang berhadapan langsung dengan konsumen (FO, admin, HRD, IT) serta konsumen, sebagaimana dijabarkan dalam Tabel 1 berikut ini:

\begin{tabular}{llcl}
\hline & & Tabel 1. Informan Penelitian \\
\hline No. & Nama & Usia & \multicolumn{1}{c}{ Posisi } \\
\hline 1. & Ustadz Mansyur & 76 & Dewan Syariah \\
\hline 2. & Pak Abdullah & 53 & Direktur Operasional/Pemegang Saham \\
\hline 3. & Pak Ayub & 35 & Manajer \\
\hline 4. & Ibu Salmiah & 34 & Staf Administrasi \\
\hline 5. & Pak Arman & 31 & Human Relations Department (HRD) \\
\hline 6. & Pak Rahman & 31 & Founding Officer (FO) \\
\hline 7. & Pak Agus & 30 & Supervisi/ Senior Founding Officer \\
\hline 8. & Pak Mahyuddin & 27 & Information and Technology (IT) \\
\hline 9. & H. Rahman & 51 & Customer \\
\hline 10. & H. Bollo & 49 & Customer \\
\hline
\end{tabular}


Proses analisis data dimulai dengan menelaah transkrip hasil wawancara yang kemudian di kategorikan berdasarkan tema-tema yang muncul, yakni syariah, murabahah, model pembiayaan, wanprestasi, strategi pemasaran. Analisis selanjutnya dikaitkan dengan domain-domain tertentu, yakni domain secara struktural (direktur, manajer, staf) dan domain even (promosi, pameran), dan domain kegiatan yang berkaitan dengan pembiayaan (strategi).

Penelitian dilakukan atas izin perusahaan yang bersangkutan. Wawancara dengan menggunakan pedoman wawancara dan perekaman dilakukan atas izin informan. Semua nama informan yang berpartisipasi disamarkan. Demikian halnya nama perusahaan pembiayaan sebagai setting penelitian ini diganti menjadi PT. Armada Finance. Hal ini dilakukan untuk menjaga identitas informan dan kerahasiaan data perusahaan.

\section{PBI dan Prinsip Syariah Dalam Pembiayaan}

Bank Indonesia pada tanggal 15 Maret 2012, menerbitkan Surat Edaran bernomor 14/10/DPNP terkait Loan to Value Ratio (LTV) Kredit Pemilikan Rumah (KPR) dan uang muka (down payment/DP) Kredit Kendaraan Bermotor $(\mathrm{KKB})$. Aturan ini muncul atas dasar penilaian Bank Indonesia terkait peningkatan permintaan KPR dan KKB yang harus diiringi dengan peningkatan kehati-hatian bank selaku penyalur KPR dan KKB. Surat edaran ini menetapkan LTV maksimal 70\% untuk kredit kepemilikan rumah dengan kriteria tipe bangunan di atas $70 \mathrm{~m} 2$. Pengaturan ini dikecualikan terhadap KPR dalam rangka pelaksanaan program perumahan pemerintah. Pengaturan DPKKB terbagi dalam tiga ketentuan: Pertama, DP minimal 25\% diperuntukkan bagi pembelian kendaraan bermotor roda dua. Kedua, DP minimal 30\% bagi pembelian kendaraan bermotor roda empat untuk keperluan nonproduktif. Ketiga, DP minimal 20\% untuk pembelian kendaraan bermotor roda empat atau lebih yang digunakan untuk keperluan produktif atau bila memenuhi salah satu syarat yang ditetapkan Bank Indonesia, yakni kendaraan angkutan orang/barang yang memiliki izin yang dikeluarkan oleh pihak berwenang untuk melakukan kegiatan usaha tertentu, atau diajukan oleh perorangan atau badan hukum yang memiliki izin usaha tertentu yang dikeluarkan oleh pihak berwenang dan digunakan untuk mendukung kegiatan operasional usaha yang dimiliki.

Aturan ini kemudian direvisi pada tahun 2015 dengan keluarnya Peraturan Bank Indonesia No.17/10/PBI/2015 tanggal 18 Juni 2015 tentang Rasio Loan to Value atau Rasio Financing to Value untuk Kredit atau Pembiayaan Properti dan 
Uang Muka untuk Kredit atau Pembiayaan Kendaraan Bermotor. Peraturan Bank Indonesia (PBI) ini adalah seperangkat aturan yang merupakan norma yang harus dipatuhi oleh semua institusi jasa keuangan yang terkait dengan kredit pembiayaan. Salah satu item yang diatur didalamnya adalah uang muka minimal untuk kredit kendaraan roda 3 ke atas, yakni DP minimal 20\% untuk jenis kendaraan umum dan barang, serta $25 \%$ untuk kendaraan pribadi.

Penerbitan aturan ini merupakan tantangan bagi perusahaan pembiayaan karena sangat memengaruhi minat pembelian kendaraan secara kredit sebagai dampak dari besaran DP minimal untuk sebuah transaksi pembiayaan kendaraan. Tujuan dari peraturan ini diterbitkan BI adalah untuk meminimalkan permasalahan terkait gagal bayar pada setiap transaksi pembiayaan, sehingga memberlakukan aturan penetapan batas minimal DP sampai pada rasio kelayakan sebuah kredit. Misalnya, DP minimal 25\% untuk mobil pribadi dan $20 \%$ untuk mobil angkutan umum dan motor.

Bentuk pembiayaan PT. Armada Finance selain mengikuti PBI juga mengaplikasikan pendanaan dengan prinsip syariah yang disebut murabahah. Prinsip syariah sendiri menurut Antonio (2001:78-79) semula berarti jalan, memuat satu sistem norma Ilahi yang mengatur hubungan manusia dengan Tuhannya, manusia dengan manusia, dan manusia dengan alam. Pada garis besarnya aturan-aturan tersebut dikelompokkan pada dua bahagian yaitu ibadah (hubungan antara makhluk dan Tuhannya dengan merujuk pada Al-Quran dan Hadist) dan mua'malah (aturan-aturan dalam konteks hubungan sesama manusia, termasuk dalam hukum perdagangan). Syariah mempunyai keunikan tersendiri karena bersifat komprehensif dan universal. Universal bermakna bahwa syariah dapat diterapkan dalam setiap waktu dan tempat oleh setiap manusia. Keuniversalan ini terutama pada bidang sosial (ekonomi) yang tidak membeda-bedakan antara kalangan muslim dan non-muslim, yang menurut Kartajaya dan Sula (2006:45-49) merupakan bisnis yang santun, penuh kebersamaan dan penghormatan atas hak masing-masing pihak. Murabahah berasal dari kata ribh'u (keuntungan) yang dapat didefinisikan sebagai produk perbankan syariah berdasarkan prinsip jual beli bukan pinjaman uang sebagimana pada pembiayaan konvensional. Akad ini merupakan aspek inti dari pembiayaan karena akad adalah perjanjian atau kontrak yang mengikat antara kedua belah pihak tentang sesuatu hal yang tidak melanggar syariat Islam dan menimbulkan hak dan kewajiban yang disepakati oleh masingmasing pihak yang terlibat. 
PBI ini sangat terkait dengan pembiayaan syariah berdasarkan prinsip murabahah pada akad kreditnya. Pada akad itu tidak diatur batas minimal DP sebagaimana yang diatur dalam PBI. Hal tersebut terjadi karena selama ini model akad murabahah prinsipnya didasarkan pada 'kesepakatan', sehingga DP dapat disepakati di bawah 20\%. Model inilah yang selama ini menarik minta para konsumen, terutama oleh pengusaha karena dapat memeroleh kendaraan yang diinginkan dengan modal awal rendah (DP rendah). Pasca penetapan Peraturan Bank Indonesia No.17/10/PBI/2015 tanggal 18 Juni 2015 tentang Rasio Loan to Value minimal 20\% berkonsekuensi pada menurunnya minat konsumen akibat dari semakin besarnya beban DP tersebut.

Perbedaan mendasar antara pembiayaan konvensional dan syariah terletak pada perjanjian bisnisnya (akad). Pembiayaan konvensional menggunakan prinsip pinjaman modal dengan pengembalian pokok beserta bunga (yang dalam hukum Islam dianggap riba), sedangkan pembiayaan murabahah mengandung prinsip jual-beli dimana jual-beli itu dengan margin keuntungan dan angsuran adalah syah dalam hukum Islam. Pada akad pembiayaan konvensional, konsumen meminjam uang kepada perusahaan pembiayaan untuk membeli mobil, misalnya, dengan jaminan mobil tersebut dan kewajiban membayar angsuran dengan bunga. Sedangkan pada akad pembiayaan syariah, perusahaan pembiayaan membeli kendaraan menggunakan harga dialer (harga diketahui oleh konsumen) dan dijual lagi kepada konsumen dengan harga sesuai kesepakatan (DP, angsuran, dan margin keuntungan).

Bagaimana dengan PBI? Dalam kaitan dengan ini, Direktur Operasional PT. Armada Finance (Pak Abdullah, 53 tahun) mengatakan bahwa sejak pemberlakuan PBI, ini sekurang-kurangnya memiliki dua dampak dalam bisnis pembiayaan berbasis syariah. Pertama, kesepakatan terkait DP (dimana jumlah dan lama angsuran merupakan ranah negosiasi) yang selama ini (sebelum penetapan BI) menjadi daya tarik pembiayaan syariah karena akadnya lebih fleksibel daripada model pembiayaan konvensional dengan pola penetapan DP dan angsuran. Ini memengaruhi pangsa pasar karena terkait dengan kemampuan memenuhi batas minimal DP oleh konsumen, terutama konsumen pada segmen usaha yang sebelumnya dapat membeli kendaraan dengan atau tanpa DP (negosiasi pada akad). Kedua, berkurangnya resiko bisnis bagi perusahaan pembiayaan, terutama karena dengan DP tinggi akan mengurangi jumlah angsuran bulanan, sehingga potensi untuk gagal bayar akan berkurang. Selama ini wanprestasi pada PT. Armada Finance lebih banyak diselesaikan secara baik-baik, atau dengan memberikan berbagai kemudahan pada para 
pelanggan, sebagai bagian dari prinsip bisnis syariah. Misalnya, penyitaan unit secara paksa sedapat mungkin tidak dilakukan, seperti yang dipraktikkan perusahaan pembiayaan lainnya. Pemberian kemudahan pada nasabah didasarkan pada keinginan konsumen untuk membayar tunggakan. Bahkan dalam beberapa kasus mereka hanya dibebankan angsuran pokok saja diluar keuntungan. Pada kasus-kasus seperti, dewan syariah berperan signifikan dalam memberikan pertimbangan.

Peraturan bisnis pembiayaan syariah ditujukan untuk kebaikan hubungan berekonomi sesama manusia harus mengandung ciri untuk kemaslahatan umum. Oleh karena itu, kehadiran sistem syariah dalam transaksi antar individu dan lembaga harus menempatkan dalam konteks pasar. Hal ini dilakukan karena adanya kebutuhan dan ketersediaan serta atas dasar pertimbangan rasional dan moral untuk mencapai kehidupan yang lebih sejahtera lahir dan batin (termasuk menentukan DP, waktu dan jumlah angsuran). Oleh karena pembiayaan berdasarkan syariah yang dijalankan PT. Armada Finance dijalankan atas prinsip kesempurnaan kehidupan antara kebutuhan lahiriah dan rohaniah dalam bertransaksi sesama hamba Allah maupun lembaga, dimana kerelaan (ridho) menjadi dasar setiap transaksi antara kedua pihak atau lebih. Dengan demikian, segala masalah yang terjadi dapat dibicarakan dan dinegosiasikan. Jikapun terjadi penarikan unit itu terjadi itu karena berbagai upaya telah dilakukan dan penarikan menjadi jalan terakhir.

Namun, kebijakan PBI terkait dengan DP tidak hanya berdampak pada perusahaan pembiayaan, tapi juga terhadap dialer atau showroom karena mengakibatkan berkurangnya jumlah unit yang terjual. Untuk itu upaya yang dilakukan dalam meningkatkan volume penjualan adalah promosi potongan harga (discounted price) atau 'subsidi DP' oleh dialer. Persentase DP dan potongan harga biasanya dilakukan ketika ada produk baru yang keluar ataukah pada saat pasar sedang lesu. Misalnya, pemberian potongan harga sebesar 15.000.000 untuk pembelian sebuah unit mobil jika pembelian dilakukan secara kredit dan 10.000 .000 jika pembelian dilakukan secara tunai.

Promosi potongan harga seperti ini memberikan dampak psikologis terhadap pengeluaran DP karena sebagian telah dikonversi dalam bentuk potongan harga menjadi DP. Jika harga kendaraan sebuah mobil, misalnya, Rp205.000.000,-, maka konsumen harus menyiapkan DP sebesar Rp51.250.000,(25\% dari total harga mobil). Namun, karena adanya potongan harga dimasukkan dalam DP sebesar Rp15.000.000,- sehingga calon pembeli cukup menyiapkan dana sebesar Rp36.250.000,- (Rp52.250.000,- dikurangi 
Rp15.000.000,-). Dari sisi konsumen, ini cukup meringankan dan untuk pembiayaan sudah tidak melanggar PBI karena flapon kredit dengan DP minimal tetap mengacu pada kisaran yang ditentukan Bank Indonesia (PBI). Ini berarti bahwa ada bentuk 'subsidi' dari pihak dialer untuk pembelian jenis kendaraan tertentu.

Meskipun demikian jika dicermati, potongan harga atau subsidi itu sebenarnya berada pada kisaran kenaikan harga unit kendaraan. Misalnya, harga 1 unit kendaraan pada tahun 2014 adalah Rp.197.000.000,- mendapatkan potongan Rp15.000.000,-, jadi harga pembelian sisa Rp 182.000.000,-. Jika mengacu pada harga kendaraan dengan spesifikasi yang sama, keluaran tahun 2011, harga pembeliannya sebesar Rp 76.000.000,-- Hal ini berarti ada kenaikan harga sekitar Rp 21.000.000,-, dengan mengacu pada harga pembelian kenaikan sekitar 6 juta (kisaran kenaikan harga setiap unit produk baru adalah Rp 6.000.000,- - Rp 10.000.000,- dari produk sebelumnya) yang disesuaikan dengan tingkat inflasi pada saat itu. Ini berarti konsumen telah membeli dengan harga yang sebenarnya. Perusahaan memberikan harga promosi yang merupakan harga perolehan plus potongan harga (lihat Tabel 2). Di satu sisi, potongan harga itulah yang disebut sebagai 'harga diskon/subsidi $\mathrm{DP}^{\prime}$ untuk menarik calon pembeli karena seakan mendapatkan 'keringanan $\mathrm{DP}^{\prime}$. Di sisi lain, diskon/subsidi DP adalah strategi untuk tetap pada aturan DP minimal sebagaimana diatur dalam PBI karena jumlah diskon/subsidi tersebut dikonversi menjadi total DP dari konsumen. Melalui strategi ini, konsumen mendapatkan 'keuntungan psikologis'.

\begin{tabular}{cccc}
\hline \multicolumn{4}{c}{ Tabel 2. Harga: Promosi, Potongan dan Perolehan } \\
\hline Tahun Keluaran & Harga Promosi & Potongan Harga & Harga Perolehan \\
\hline 2011 & & & Rp 176.000.000 \\
\hline 2014 & Rp197.000.000 & Rp 15.000.000 & Rp 182.000.000 \\
\hline
\end{tabular}

Bagi PT. Armada Finance, promosi harga diskon/subsidi DP merupakan strategi bisnis dari para produsen/dialer. Pihak perusahaan pembiayaan hanyalah membiayai pembelian sesuai harga pembelian. Meskipun dalam akad kerjasama tetap tertulis sesuai harga brosur, DP tetap mengacu pada aturan kelayakan kredit. Artinya, DP terdiri atas potongan harga/subsidi DP ditambah setoran DP konsumen. Pertanyaannya adalah apakah ini sejalan dengan prinsip syariah? Dalam konteks kebijakan-kebijakan seperti ini peran dewan syariah ialah tetap menjaga agar aktivitas bisnis perusahaan tetap 
berada pada rambu-rambu syariah, yang akan didiskusikan dalam kaitan dengan wanprestasi dan penanganannya berikut ini.

\section{Wanprestasi dan Penanganannya}

PT. Armada Finance sebagai sebuah lembaga pembiayaan berperan sebagai salah satu lembaga sumber pembiayaan alternatif masyarakat dalam hal permodalan atau pendanaan, termasuk dalam pengadaan kendaraan melalui pembelian kredit. Dalam praktek transaksi jual-beli secara kredit terlebih dahulu dilakukan perjanjian jual-beli yang isinya mengatur hak dan kewajiban masing-masing pihak yang terlibat dalam transaksi tersebut. Ketika ada salah satu pihak yang tidak mematuhi perjanjian tersebut maka hal itu disebut wanprestasi.

Bentuk penanganan wanprestasi pun berbeda sesuai dengan jenis dan resiko yang ditimbulkan terhadap perusahaan dan tetap mengacu pada etika bisnis Islami. Etika bisnis Islami menurut Badroen (2006:46-50) dapat dilihat pada kehidupan Rasululah SAW, di antaranya adalah memberi kemudahan bagi orang lain, tanpa paksaan, memberi tenggang waktu apabila pengutang (kreditor) belum mampu membayar. Etika bisnis dalam PT. Armada Finance dikemas dalam slogan: 'Berbisnis, amanah, ikhlas, jujur dan istiqomah', sebuah slogan yang sangat abstrak dan dalam prakteknya bersifat kasuistik. Dalam kaitan dengan pembiayaan oleh Agus (30th), sepervisi PT. Armada Finance dijelaskan bahwa bentuk wanprestasi yang terjadi menyangkut gagal bayar, pengalihan kendaraan jaminan, dan penggelapan jaminan. Lebih lanjut dijelaskannya bahwa ini tidak hanya terjadi PT. Armada Finance di pembiayaan lainnya juga mengalami hal yang sama.

Gagal bayar adalah salah satu bentuk wanprestasi yang dihadapi oleh PT. Armada Finance. Ini biasanya terjadi karena konsumen misalnya mendapatkan musibah (bangkut, meninggal, PHK). Pada kondisi ini konsumen dianggap tetap memiliki itikad baik untuk membayar hanya saja sedang mengalami kesulitan keuangan. Ada berbagai kebijakan yang terkait gagal bayar yang diberikan kepada konsumen. Salah satunya adalah dengan tetap menagih dan memberikan keringanan-keringanan kepada konsumen, seperti membayar pokok utang saja. Kebijakan lainnya adalah pembatalan perjanjian atau pemecahan perjanjian dengan restrukturisasi utang atau pengembalian barang jaminan. Kebijakan ini bertujuan untuk membawa kedua belah pihak kembali pada keadaan sebelum perjanjian ditiadakan. Artinya bahwa pihak konsumen maupun pihak perusahaan mengupayakan solusi terbaik dari masalah tersebut 
dengan mempertimbangkan hak dan kewajiban masing-masing pihak dan unit yang dibiayai. Jadi dalam konteks ini peniadaan perjanjian setelah melakukan proses hitung kewajiban yang masuk dengan nilai asset yang dijaminkan.

Pengalihan jaminan adalah bentuk wanprestasi lainnya, yakni kondisi di mana konsumen mengalihkan kendaraan jaminan tanpa sepengetahun pihak PT. Armada Finance. Biasanya hal ini dilakukan oleh konsumen yang kesulitan dalam melakukan kewajibannya sesuai akad, maka mengalihkan kendaraan ke pihak lain dengan alasan bahwa tidak mengalami banyak kerugian akibat dari akad yang telah disepakati. Jika pengalihan dilakukan melalui perusahaan pembiayaan konsumen akan mengalami banyak masalah administrasi seperti batalnya asuransi kendaraan atau dibebankannya angsuran baru bagi pembeli, karena akad sebelumnya dengan sendirinya menjadi batal. Artinya, ia harus melalui proses pembuatan akad baru dan jaminan asuransi baru yang berarti ada tambahan biaya. Dalam kondisi seperti ini pihak PT. Armada Finance melakukan tindakan dengan melacak kepada siapa kendaraan dialihkan dan bilamana telah diketahui, lalu dilakukan pengawasan ketat terhadap unit yang dialihkan tersebut. Biasanya kasus pengalihan ini tidak muncul di permukaan selama pembayaran angsuran tetap lancar. Tindakan PT. Armada Finance dalam situasi seperti ini lebih pada mengamankan asset dan bagi konsumen yang melakukan wanprestasi dimasukkan dalam daftar hitam (black list).

Penggelapan jaminan adalah bentuk wanprestasi yang paling fatal dihadapi oleh PT. Armada Finance. Biasanya ini terjadi ketika FO kurang teliti dalam menetapkan calon konsumen, sehingga FO juga harus menanggung konsekuensinya, mulai dari yang berupa teguran sampai pada resiko tanggung bersama. Resiko tanggung bersama mencakup denda yang terjadi ketika FO melakukan pelanggaran terkait upaya meloloskan berkas konsumen sementara berkas tersebut tidak memenuhi syarat atau kurang meyakinkan. Menurut Salmiah (34 tahun, staf administrasi perusahaan), biasanya hal ini terjadi jika ada hubungan emosional antara calon konsumen dan FO atau ketika seorang FO sedang dalam tuntutan target penjualan. Langkah konkret perusahaan dalam kondisi seperti ini adalah berusaha mencari keberadaan unit kendaraan dan melaporkan konsumen dan kendaraan ke pihak berwajib. Kondisi ini telah berada pada ranah hukum pidana dan oleh perusahaan dianggap sebagai itikad buruk dari konsumen dan pihak lain yang terlibat dalam proses tersebut. 


\section{Strategi Pemasaran Pembiayaan PT. Armada Finance}

Ada berbagai strategi promosi yang digunakan untuk menarik perhatian calon konsumen yang akan menggunakan perusahaan ini sebagai pembiayaan atas unit yang dibeli, yakni kemudahan layanan, proaktif, fleksibilitas pembiayaan dan margin kompetitif, pembiayaan bebas riba, pertemanan dan kekerabatan, fokus pada pegawai negri dan karyawan swasta, mengikuti pameran otomotif, dan layanan purna jual. Strategi dimaksud dalam hal sebagai seperangkat gagasan yang diwujudkan dalam bentuk tindakan-tindakan oleh pada karyawan perusahaan.

\subsection{Kemudahan Layanan}

Strategi kemudahan layanan adalah salah satu cara mendapatkan konsumen potensial untuk dibiayai oleh perusahaan pembiayaan. Bentuk kemudahan layanan berupa penjemputan berkas calon konsumen dengan mempersingkat proses layanan berkas dari permohonan hingga pada keputusaan pemcairan kredit. Bentuk kemudahan layanan ini sudah menjadi SOP perusahaan dengan menyiapkan hotline yang aktif selama 24 jam yang siap melayani setiap telpon yang masuk. Selain itu, pemroses berkas dilakukan tidak lebih dari 24 jam sepanjang persyaratan berkas terpenuhi.

Bentuk kemudahan layanan lainnya yang tidak diatur oleh perusahaan namun merupakan kreatifitas dari FO, yakni pelayanan yang bersifat personal, sehingga memberi kesan bagi calon konsumen seperti diutamakan, misalnya ketika ada berkas yang harus difotokopi biasanya FO tersebut berinisiatif menawarkan diri untuk mengkopikan berkas tersebut, bahkan pada beberapa kasus biasanya FO yang sudah dipercaya oleh konsumen dititipkan uang angsuran untuk dibayarkan angsurannya. Meskipun sebenarnya FO memberikan perlakuan yang sama pada setiap calon pelanggannya, dalam prakteknya, layanan personal dapat berbeda-beda antar FO yang satu dengan yang lainnya dan antar FO dengan calon konsumen, tergantung pada layanan kemudahan apa yang dibutuhkan.

Bentuk kemudahan lainnya adalah kemudahan mendapatkan unit. Pada umumnya konsumen menginginkan untuk segera mendapatkan unit yang dibelinya. Untuk maksud itu mereka tidak mau menunggu lama dalam antrian inden meskipun sehingga terkadang mereka bersedia membayar lebih demi mendapatkan antrian terdepan. Oleh karena unit yang ditawarkan pada saat pameran umumnya terbatas dan merupakan produk terbaru sehingga 
konsumen selalu ingin dikedepankan. Keuntungan dari PT. Armada Finance dalam situasi seperti ini adalah mendapat skala prioritas dalam setiap penjualan unit kendaraan. PT. Armada Finance dengan berbekal status sebagai perusahaan yang berada dalam group yang sama dengan salah satu perusahaan penyuplay kendaraan memungkinkan setiap ada stok yang masuk, PT. Armada Finance selalu mendapatkan jatah pertama sebelum diberikan kepada perusahaan pembiayaan yang lain.

\subsection{Proaktif}

Sulitnya menemukan calon konsumen merupakan masalah yang umum dialami oleh pemasar produk. Tantangan tersebut harus dilalui oleh FO karena dalam kontrak kerja mereka telah tercantum diktum bahwa calon pelanggan harus memenuhi target penjualan 12 unit per bulan. Jika seorang FO tidak mencapai target, maka ia akan mendapatkan SP-I (surat peringatan pertama), selanjutnya ketika bulan berikut tidak juga tercap,ai maka akan keluar SP-2 (surat peringatan kedua). Untuk kondisi berikut seorang FO dengan sendirinya akan mengurdurkan diri karena SP-3 identik dengan black list, yang artinya mereka yang masuk dalam kategori ini tidak akan diterima bekerja di tempat lain.

Untuk itu diperlukan sikap yang proaktif untuk mencapai target tersebut. Menurut seorang FO bernama Agus, bahwa sikap proaktif yang dilakukannya dalam memenuhi target adalah (1) bergabung ke komunitas-komunitas mobil tertentu, (2) aktif mengunjungi usaha-usaha rental, misalnya kelompok rental, (3) melakukan promosi melalui media-media sosial, pameran otomotif oleh agen pemegang merek (APM) atau showroom mobil, warung kopi/cafetaria, dan door to door terutama kompleks-kompleks perumahan, dan (4) melakukan perbaharuan informasi secara rutin, terutama kelebihan-kelebihan akan produk yang dijual baik dari produk kendaraan, seperti tipe kendaraan serta kelebihan dan kekurangannya maupun produk skema pembiayaan seperti skema dan bunga pinjaman pembiayaan. Dengan cara demikian Agus memperluas jaringannya tidak hanya untuk memenuhi target penjualan perusahaan, tapi juga membantu mencarikan pembeli untuk kendaraan lama yang ingin dijual pemiliknya. Dengan cara demikian, ia mendapatkan penghasilan lain diluar gaji dan bonus dari perusahaan pembiayaan tempatnya bekerja.

Selain proaktif dari sisi FO secara personal, ini juga dilakukan oleh perusahaan secara institusional dengan ikut dalam tim pabrikan tertentu atau showroom 
tertentu dimana FO bekerja sama dengan marketing counter perusahaan mobil. Ini dilakukan dengan melampirkan brosur pembiayaan pada outlet promosi kendaraan. Pengunjung pameran biasanya langsung mengambil brosur mobil atau diberikan oleh marketing counter berupa brosur mobil yang dibawahnya telah terlampir daftar harga mobil dengan skema pembiayaannya. Model promosi seperti ini merupakan pola hubungan simbiosis mutualisme antara marketing counter kendaraan dari perusahaan tertentu dengan staf pembiayaan (funding officer) dari perusahaan pembiayaan.

\subsection{Fleksibilitas Pembiayaan dan Harga kompetitif}

Fleksibilitas pembiayaan adalah strategi pemasaran lainnya untuk menarik perhatian konsumen. Oleh karena harga pembelian telah ditentukan oleh dialer, maka perusahaan pembiayaan hanya akan menyesuaikan harga tersebut. Perusahaan pembiayaan hanya dapat memberikan pinjaman dengan bunga rendah (negosiasi bunga). Hal ini kemudian terkait jumlah DP dan jangka waktu angsuran. Model ini direspon baik oleh calon konsumen, terutama calon konsumen yang anti-riba, karena ada peluang tawar-menawar, tinggi rendahnya pembiayaan, karena itu tergantung dari hasil kesepakatan. Ini yang membuatnya berbeda dengan perusahaan pembiayaan konvensional yang hanya ditetapkan oleh pihak perusahaan.

Misalnya, dalam perusahaan pembiayaan konvensional ketika berbicara bunga pembiayaan, maka pada seorang calon konsumen ditetapkan bahwa pembiayaan selama lima tahun bunganya 9\%, dengan DP yang ditetapkan sebesar $20 \%$ dari nilai unit. Sedangkan dalam model pembiayaan syariah pada PT. Armada Finance, DP dan jumlah keuntungan tidak ditetapkan, meskipun tetap ada skema yang ditawarkan kepada calon konsumen, diikuti dengan tawar-menawar dan lahirlah kesepakatan. Salah satunya dalam bentuk penerapan angsuran rendah dengan jangka waktu angsuran yang lebih panjang. Selama penerapannya pada segmen kendaraan angkut barang atau angkutan umum. Berbeda halnya jika kendaraan pribadi yang segmennya berupa DP yang lebih tinggi agar angsurannya lebih rendah. Misalnya, H. Rahman (51 tahun) yang membeli sebuah mobil untuk kebutuhan usaha rental. Baginya, pembelian 4 unit di PT. Armada Finance, hanya dibebankan DP 10\% dengan gratis asuransi total lost only (TLO). TLO merupakan klaim asuransi jika terjadi kerusakan unit minimal $80 \%$ atau unit hilang dengan nilai asuransi sebesar harga unit yang diasuransikan. Jadi pada pola TLO tanggungan terhadap unit sepenuhnya pada konsumen ketika kerusakan di bawah $80 \%$ berdasarkan penilaian dari perusahaan pembiayaan. 


\subsection{Pembiayaan Bebas Riba}

Muamalah oleh PT. Armada Finance dianggap mempunyai konsep dasar kuat, yang membedakannya dengan perusahaan pembiayaan lainnya, karena didalamnya tidak mengandung unsur riba. Pembiayaan murabahah adalah akad jual beli antara perusahaan dengan konsumen, dimana barang dijual dengan harga asal dengan tambahan keuntungan yang telah disepakati oleh kedua belah pihak (perusahaan dan konsumen). Konsep dasar dari murabahah selalu mengikuti ketentuan-ketentuan Syariah Islam yang menyangkut masalah muamalah yang dikhawatirkan akan mengandung unsur riba.

Prinsip dan mekanisme pembiayaan berbasis murabahah yang dijalankan adalah berdasarkan prinsip pembiayaan yang bersifat Ilahiyah yang meliputi keadilan, kebersamaan, tanpa merugikan pihak-pihak yang bersangkutan dalam proses muamalah tersebut. Misalnya, H. Bollo (49 tahun), membeli sebuah mobil keluaran tahun 2012 secara kredit. Setelah berdiskusi dengan Agus, salah seorang FO dari PT. Armada Finance, lalu disepakati bahwa perkiraan keuntungan yang awalnya 9\% turun menjadi 7\%. Prinsip bebas riba dalam transaksi ini adalah prinsip jual-beli, bukan membungakan uang. Prinsip ini dikedepankan dalam menyampaikan promosi ke masyarakat sebagai bagian dari kekuatan bisnis yang tidak dimiliki oleh perusahaan pembiayaan konvensional.

Slogan pembiayaan syariah sebagai sebuah strategi memiliki segmen pasar yang besar, khususnya ummat Islam yang pada prinsipnya tidak setuju dengan riba. Dengan mengedepankan slogan bebas riba ini tidak saja menarik perhatian calon konsumen ummat Islam, tapi juga menjadi keunggulan dan keunikan perusahaan dalam sistem pembiayaan jika dibandingkan dengan sistem pembiayaan konvensional.

\subsection{Pertemanan dan Kekerabatan}

Menjalankan bisnis bersama dengan teman atau keluarga sendiri menjadi strategi tersediri bagi pemasar produk. Adanya kesamaan-kesamaan persepsi dan keakraban dalam berteman dapat menjadi modal bersama untuk membangun sebuah usaha ataupun bisnis. Begitu juga dalam bekerja, kekompakan yang sudah ada dalam persahabatan juga dapat menjadi modal kerja untuk menghasilkan sesuatu yang maksimal.

Jaringan pertemanan merupakan salah satu cara yang efektif untuk mendapatkan pelanggan seperti yang diungkapkan oleh Salmiah, salah seorang 
staf administrasi PT. Armada Finance, bahwa cara paling bagus mendapatkan pelanggan adalah lewat jaringan pertemanan maupun keluarga. Ini didasarkan pada asumsi, bahwa mereka tidak mungkin merekomendasikan orang yang tidak dikenal dan tidak serius. Ini berarti bahwa kemungkinan terjadi transaksi jual-beli lebih besar dengan nasabah dari hasil rekomendasi dari kerabat. Artinya pertemanan atau kekerabatan menjadi modal sosial bagian pemasaran dalam bisnis pembiayaan seperti ini. Seperti hubungan bisnis antara Agus sebagai FO perusahaan dan H. Bollo sebagai konsumen yang merupakan hasil rekomendasi dari kerabatnya.

\subsection{Fokus pada Pegawai Negeri dan Karyawan Swasta}

Dalam perencanaan pemasaran produk perusahaan, penentuan target pemasaran didahulukan, sehingga marketing dapat berfokus dalam bekerja, meskipun tidak mengabaikan target lainnya. Target pemasaran PT. Armada Finance difokuskan pada pegawai, baik pegawai negeri sipil maupun pegawai swasta, atau pengusaha tergantung dari jenis usaha dan tipe mobil yang hendak dipasarkan.

Pemilihan pegawai negeri maupun pegawai swasta didasarkan pada pertimbangan keamanan dalam pemberian kredit dikarenakan mekanisme penggajian mereka yang memudahkan dalam penagihan secara teratur maupun penafsiran besaran pendapatan perbulannya. Mereka yang ditargetkan dari segmen ini adalah yang tergolong kelas menengah ke atas. Penargetan ini ini sangat menjanjikan mengingat pembayaran dalam bentuk pemotongan gaji secara langsung setiap bulan, gagal bayar dapat dihindari, dan dengan demikian likuiditas atau kolektibilitas neraca pembayarannya terjamin.

Untuk merebut pasar pada segmen ini, perusahaan memberikan promo DP murah atau angsuran murah, dengan cukup melampirkan SK sebagai jaminan dan kerjasama dengan bendahara dari instansi tempat mereka bekerja. Promosi ini sebenarnya meskipun diwacanakan sebagai DP murah, namun tetap tidak melanggar aturan PBI karena tetap tertulis dalam akad sebanyak 25\%, meskipun konsumen hanya menyiapkan $10 \%$, sisanya itu dalam bentuk subsidi atau diambil dari potongan harga.

\subsection{Keikutsertaan pada Pameran Otomotif}

Strategi lainnya yang dilakukan untuk memromosikan pembiayaan adalah mengikuti pameran otomotif bekerjasama dengan perusahaan produsen yang 
menyiapkan unit mobil untuk dibiayai oleh perusahaan. Pameran otomotif biasanya dilakukan oleh perusahaan produsen otomotif tertentu yang dilakukan pada saat memromosikan produk terbaru atau pameran tahunan, seperti Indonesian International Motor Show (tingkat internasional) dan Jakarta Auto Show (JAS) yang diadakan oleh Gaikindo (tingkat nasional) serta Pameran Otomatif Makassar (tingkat lokal).

Perusahaan pembiayaan mengutus karyawannya pada saat pameran di stan perusahaan otomotif tertentu sebagai bagian dari peserta pameran. Pada stan itu ada berbagai perusahaan pembiayaan lainnya yang turut serta, sehingga persaingan antar perusahaan pembiayaan cukup ketat. Pada kondisi seperti inilah setiap perusahaan pembiayaan harus mampu menunjukkan kelebihan masing-masing dari segi produk pembiayaannya. Salmiah (34 tahun), salah seorang staf administrasi), mengungkapkan pengalamannya bahwa dalam mengikuti pameran seperti ini, persaingan terjadi pada kisaran besaran bunga yang ditawarkan oleh masing-masing pembiayaan. Keuntungan dari PT. Armada Finance adalah pada skema pembiayaan syariahnya yang tidak mengandalkan bunga (yang dalam hukum Islam dianggap riba), tapi mengandalkan prinsip jual beli dengan keuntungan. Segmen pasar ini (mereka yang anti-riba) sulit dimasuki oleh pembiayaan konvensional karena prinsip tadi. Meskipun skema pembiayaan berdasarkan syariah diberikan juga oleh perusahaan pembiayaan lainnya, namun PT. Armada Finance telah populer karena dianggap 'pemain lama' dan telah 'memiliki nama' sebagai perusahaan pembiayaan berbasis syariah yang profesional.

\subsection{Layanan Purna Jual}

Layanan purna jual adalah layanan oleh perusahaan setelah proses transaksi jual beli. Layanan ini mencakup kemudahan-kemudahan yang diberikan oleh perusahaan terkait dengan pemeliharaan kendaraan. Misalnya, jika ada kerusakan dari satu tipe produk, konsumen seringkali menghadapi kendala dalam memperbaikinya karena ketiadaan suku cadang. Itulah sebabnya produsen dalam pemasaran produk terbarunya sudah dipaketkan dengan suku cadang pada dialer resmi. Keuntungan dari PT. Armada Finance dalam konteks ini adalah produk yang dipasarkannya adalah produk yang suku cadangnya mudah diperoleh karena produk pemasarannya masih pada satu unit kendaraan. Inilah kemudian yang menjadi nilai lebih dari perusahaan ini dengan layanan menfasilitasi pembelian suku cadang sesuai pesanan konsumen. Pada perusahaan pembiayaan lainnya mereka sepenuhnya menyerahkan hal tersebut kepada pihak bengkel dan konsumen serta asuransi. 
Aspek lain yang menyangkut layanan purna jual adalah soal garansi dalam jangka waktu tertentu yang diberikan produsen/penyalur produk atau kreditur kepada konsumennya. Layanan purna jual yang berikan oleh PT. Armada Finance adalah setiap transaksi harus dijaminkan pada asuransi sebagaimana pada perusahaan pembiayaan lainnya. Perusahaan ini menjual unit dengan paket asuransi yang bekerja sama dengan asuransi bereputasi dan profesional dengan layanan respon cepat dalam klaim nasabah, sehingga keluhan tereliminir.

Meskipun semua perusahaan pembiayaan juga menerapkan strategi ini, namun biaya asuransi di PT. Armada Finance memberlakukan premi yang lebih rendah dibandingkan premi asuransi lainnya. Ini dimungkinkan karena perusahaan asuransi yang kerjasama dengan PT. Armada Finance juga bekerjasama dalam melayani klaim asuransi dengan bengkel yang pemiliknya adalah pemegang saham dari PT. Armada Finance. Agus, salah seorang FO dari PT. Armada Finance, menyatakan bahwa premi asuransi di perusahaan asuransi tertentu untuk jenis kendaraan dengan rentang harga antara Rp150.000.000,- dan Rp300.000.000,-, maka asuransi semua resiko sebesar 2\% dari harga unit (antara Rp3.000.000,- dan Rp6.000.000,-) dan total lost only (TLO) sebesar 0,8\% dari harga unit (antara Rp1.200.000,-), sedangkan yang ditawarkan oleh PT. Armada Finance persentasenya dapat lebih rendah sesuai dengan hasil negosiasi antara pihak yang terlibat. Artinya, PT. Armada Finance dapat memenangkan pasar dengan memberikan penawaran biaya asuransi yang lebih rendah dibandingkan dengan perusahaan pembiayaan lain dengan paket asuransinya. H. Rahman (51 tahun), misalnya, yang membeli empat unit mobil untuk kebutuhan usaha rental diberikan asuransi TLO secara gratis sebagai bagian dari bonus pembelian. Namun, ia kemudian memilih paket asuransi all risk. Dengan demikian, ia tinggal menambahkan selisih dari premi paket TLO ke all risk. Pilihan itu dilakukan karena all risk menanggung semua resiko terkait dengan kendaraan. Berbeda dengan TLO yang hanya menanggung ketika kerusakan kendaraan minimal 80\% atau hilang.

\section{Kesimpulan}

Menjamurnya perusahaan pembiayaan membuat persaingan antar perusahaan menjadi begitu ketat, yang membuat PT. Armada Finance berupaya untuk merebut pasar dengan berbagai kebijakan tanpa melanggar peraturan pemerintah yang terkait. Selain itu, perusahaan ini juga menggunakan prinsip syariah Islam (murabahah) sebagai dasar dalam memenangkan pasar sekaligus 
sebagai pembeda antara PT. Armada Finance dan perusahaan pembiayaan konvensional lainnya.

Aktivitas perusahaan pembiayaan selalu diupayakan agar berjalan sesuai dengan koridor dan tidak menimbulkan permasalahan. Namun, jika terjadi pelencengan perjanjian antar pihak-pihak terkait (wanprestasi), yang dalam konteks ini mencakup gagal bayar, pengalihan jaminan dan penggelapan jaminan, maka penyelesaiannyapun disesuaikan dengan jenis penyimpangan dan resiko yang ditimbulkan terhadap perusahaan tanpa mengabaikan etika bisnis Islami yang menjadi salah satu keunikan perusahaan ini.

Beragam strategi yang diterapkan oleh perusahaan ada yang bersifat institusional, namun ada juga yang merupakan hasil dari kretivitas karyawan pada PT. Armada Finance, yang saling berkelindan dalam prakteknya. Secara institusional, strategi tersebut meliputi kemudahan layanan, fleksibilitas pembiayaan, pembiayaan bebas riba, keikutsertaan dalam pameran otomotif, dan layanan purna jual. Sementara strategi yang berkaitan dengan kreativitas individual karyawan menyangkut sikap proaktif karyawan, pemanfaatan pertemanan dan kekerabatan dalam mencari konsumen potensial, dan menargetkan pegawai negeri serta karyawan swasta sebagai pasar paling potensial, sangat turut berkonstribusi dalam memenangkan pasar pembiayaan. Jika mengombinasikan keduanya, strategi institusional dan kreativitas individual merujuk pada apa yang disebut oleh Schein (1992) sebagai adaptasi eksternal dan integrasi internal.

Mengingat menjamurnya perusahaan pembiayaan, maka perusahaan harus senantiasa melakukan terobosan-terobosan berkaitan dengan strategi-strategi yang yang digunakan harus selalu ditingkatkan dan diadaptasikan sesuai dengan kebutuhan pasar dalam menghadapi persaingan bisnis pembiayaan yang sangat kompetitif.

\section{Daftar Pustaka}

Antonio, Muhammad Syafei. (2001). Perbankan Syariah: Prinsip, Praktik, dan Prospek. Jakarta: PT. Serambi Ilmu.

Baba, M. (2006). 'Anthropology and Business', dalam Birx, H. James (ed.), Encyclopedia of Anthropology. Thousand Oaks, CA: Sage Publications, 83-117.

Badroen, Faisal. (2006). Etika Bisnis Dalam Islam, Jakarta: Kencana Prenada Media Group. 
Gunawan, Jonathan. (2013). 'Analisa Manajemen dan Strategi Bisnis pada UD. Cahaya Abadi Indah Di Surabaya', Jurnal Agora, 1(3):1076-1081.

Kartajaya, Hermawan dan Sula, Syakir M. (2006). Syariah Marketing. Bandung: PT. Mizan Pustaka.

Kottler, John P. \& Heskett James.L. (1992). Corporate Culture \& Performance. New York: Free Press.

Lubis, Nurbaity. (2004). Strategi Pemasaran Dalam Persaingan Bisnis. Medan: Program Studi Ilmu Manajemen, Fakultas Ekonomi, Universitas Sumatera Utara.

Prawia, Des. (2015). 'Analisis Strategi Bersaing Industri Bisnis Apotek di Kota Pekanbaru', JOM FISIP, Oktober, 2(2):1-14.

Schein, Edgar H. (1992). Organizational Culture and Leadership. San Fransisco: Jossey Bass.

Sutrisno, Edy. (2011). Budaya Organisasi. Jakarta: Kencana Prenada Media Group.

Tjiptono, Fandy. (2002). Strategi Pemasaran. Yogyakarta: Andi. 